Mgr. Josef Kraus, Ph.D.

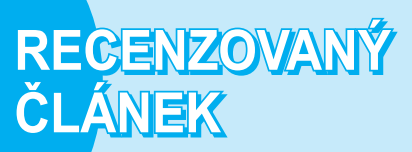

Islámský stát: aktéři konfliktu, jejich participace, motivy a cíle

\title{
Islamic state: conflict actors, their participation, motives and goals
}

Vojenské rozhledy, 2015, roč. 24 (56), č. 2, s. 20-36, ISSN 1210-3292 (tištěná verze), ISSN 2336-2995 (on-line).

\section{Abstrakt:}

Text se věnuje problematice současného konfliktu v Sýrii a Iráku, který vedl až $k$ vytvoreni tzv. Islámského státu, jedné z největšich bezpečnostnich hrozeb současného světa. Vznik tohoto kvazistátního útvaru na pozadí občanské války v Sýrii a stále ještě nevyřšeného konfliktu v Iráku je di̊sledkem participace velkého počtu vnitřnich $i$ vnějšich aktérů. Způsob jejich participace a zejména jejich cíle se pritom často diametrálně odlišují a navzdory sporadické shodě v některých dílčich bodech je nejednotný postup lokálnich a externich sil proti hrozbě Islámského státu tím hlavním dưvodem, proč toto radikální uskupení nebylo zlikvidováno či alespoň výrazně potlačeno. Cílem textu je především vysvětlit a analyzovat hlavní motivy a cile všech významných aktérů podílejicich se na tomto konfliktu a popsat způsob, jakým se odrážejí na jeho dynamice. Díky tomu lze výrazně zvýsit prehled čtenárù v této velice chaotické, nepřehledné a často dezinterpretované situaci na Blizkém východě.

\section{Abstract:}

This text is focused on current situation in Syria and Iraq and so called Islamic State, the one of the biggest threats of contemporary world. The rise of this quasistate at background of civil war in Syria and still not fully solved conflict in Iraq is the result of involvement of many internal and external actors. The form of their involvement and especially their goals are very different from each other and despite sporadic and declaratory agreements in partial points the main reason the Islamic State still exists in very good shape is disunited attitude of local and external powers against it. The main aim of this text is to explain and to analyze main motives and goals of all relevant actors and sides of mentioned conflict and describe the way they affect its dynamics. Due to that it is possible to increase the knowledge of readers in such a chaotic, unclear and often misinterpreted situation in the Middle-East.

\section{Klíčová slova:}

Islámský stát, Irák, Sýrie, terorismus, náboženský radikalismus, občanská válka, aktéři konfliktu.

\section{Keywords:}

Islamic State, Iraq, Syria, Terrorism, Religious Radicalism, Civil War, Conflict Actors. 


\section{Úvod}

Působení Islámského státu a boj proti němu ze strany široké koalice státních i nestátních aktérů je $\mathrm{v}$ současnosti značně medializovaným a také sekuritizovaným tématem. Politici, komentátoři a bezpečnostní odborníci se předhánějí v hodnocení působení islámských radikálů na území Sýrie a Iráku a navrhování vojenských postupů pro jejich eliminaci. V aktuálním bezpečnostněpolitickém diskurzu se ale přitom často zapomíná na to nejdůležitější, co determinuje aktuální stav. Tím jsou motivy a cíle dlouhé řady aktérů participujících na tomto konfliktu, které mají značný vliv na jeho vnitřní dynamiku. Tento text má za cíl charakterizovat a vysvětlit tyto skutečnosti, bez jejichž znalosti je porozumění aktuálnímu dění na Blízkém a Středním východě doslova nemožné. Bude se přitom zaměřovat na představení základních reálií syrské občanské války, genezi Islámského státu a především na představení hlavních vnitřních i vnějších aktérů. Protože informace o situaci na válčeném poli a na Islámským státem okupovaném území jsou velice špatně dohledatelné, kusé, často tendenční a podléhající cílené propagandě a mlžení, je značný problém zkoumat tuto problematiku pouze $\mathrm{v}$ závislosti na otevřených zdrojích. Terénní výzkum, rozhovory s insidery, snaha o triangulaci dat a především vlastní znalost reálií celé oblasti, vazeb jednotlivých aktérů a sil jsou naprosto klíčové pro úspěšné interpretování současných událostí. Jakkoli sám autor nepobýval delší dobu prímo na současném bojišti ani na území okupovaném a spravovaném Islámským státem, navštívil mnohokrát tento region před konfliktem i během něho, dlouhodobě sleduje aktivitu lokálních a vnějších hráčů, stejně jako udržuje kontakt místními obyvateli a zahraničními pracovníky se znalostmi místních reálií. Složitost celé problematiky a nedostatečný časový odstup od ní přitom znesnadňuje či dokonce znemožňuje v této fázi pracovat se sofistikovanějšími konceptualizacemi a teoretickými rámci. Tento text proto nemá ambici testovat teorie ani hlouběji pracovat s typologiemi konfliktních aktérů.

Přesto pro udržení jakéhosi základního rámce bude využito definic stran konfliktů na základě známého Uppsala Conflict Data Program (UCDP). [1] Ten hovoří o aktérovi jako o státním či nestátním organizovaném či alespoň formálně organizovaném uskupení. Další základní dělení aktérů je dáno mírou vlastní angažovanosti v konfliktu, a to na primární a sekundární. Zatímco primární strany konfliktu jsou definovány jako aktéri se vzájemně nekompatibilními zájmy a pozicemi, kteří jsou tedy hlavními participanty na konfliktu, se sekundárními aktéry je to složitější, protože je lze dělit na válčící a neválčící. První skupina je definována jako strana vstupující do konfliktu vlastními vojsky aktivně podporujícími alespoň jednoho z primárních aktérů. Sekundární neválčící aktéŕi jsou pak takoví, kteří poskytují podporu primárním stranám konfliktu, která nějakým způsobem ovlivňuje jeho vývoj. Myslí se tím podpora finanční, logistická, omezeně vojenská a zejména ta vedená úmyslně s cílem posílit primárního aktéra. Jak si ukážeme hned níže, tato typologie se v současném konfliktu v Sýrii a Iráku jeví jako velice omezená a silně nedostačující. Lepší to ostatně není ani v př́padě rozvoje této typologie, jak se o to pokusil např. Lukáš Dyčka [2]. Nelze ovšem v úvodu neodkázat na několik předních děl zabývajících se výzkumem konfliktů a jejich aktéry. $V$ českém prostředí lze zdůraznit práci kolektivu autorů kolem Josefa Smolíka a Tomáše Šmída, v zahraničním je třeba vyzdvihnout dílo kolem dvojice Dana Miodownik and Orena Baraka, zabývající se nestátními aktéry ve vnitrostátních konfliktech, Bjorna Mollera a jeho výjimečnou studii o roli externích aktérů v somálském konfliktu, či díla Johana 
Galtunga zabývající se teorií konfliktu. [3] Jak již bylo ale zmíněno výše, konceptualizace aktérů není hlavním cílem této práce, takže tato problematika bude nyní upozaděna větším zaměřením se na vysvětlení reálií oblasti, motivů a cílů participujících aktérů a dalších skutečností.

\section{Hlavní aktéři a vývoj jejich participace v důsledku dynamiky konfliktu}

Značná sekuritizace konfliktu na území Sýrie a Iráku ze strany politické sféry, médií a bezpečnostních odborníků se z většiny zaměřuje na otázku vojenské eliminace Islámského státu, způsoby jejího provedení a možnosti využití nejrůznějších prostředků. Mnohem méně se ale zabývá motivy a cíli primárních a sekundárních (a dalších v závislosti na použité typologii) aktérů. Ti přitom utvářejí dvě důležité charakteristiky zkoumaného konfliktu - silná vnitřní dynamika a velký počet participujících stran. Protože prostor tohoto textu je omezený, není možné se dopodrobna zabývat vznikem a vývojem události v rámci tzv. arabského jara, resp. jasmínové nákazy, jak tuto vlnu bouří v islámském světě její kritici nazývají. [4] Je ale třeba zmínit, že to, co v Sýrii začalo jako demonstrace s politicko-ekonomickými požadavky v roce 2011, se zvrhlo do masivní občanské války s důležitým náboženským charakterem a přesahem na území sousedního Iráku. A zde lze hledat základy pro genezi tzv. Islámského státu, který stojí na sunnitsko-radikální věrouce samozvaného duchovního vůdce Abú Bakra Bagdádího. Ze své podstaty se tak Islámský stát (nebo Islámský chalífát s odkazem na vůdcovství muslimské obce) vymezuje především vůči ší'itům ve svém okolí (syrské alávitské vládě, irácké ší'itské vládě, libanonskému Hizballáhu a Íránu), ale také pochopitelně vůči „nevěřícímu“ Západu a umírněným muslimům. Důležitou podstatou zkoumaného konfliktu je tak náboženská štěpící linie sunnitských povstalců vůči vládám v Sýrii a Iráku, ovládaných ší'ity. Lze zde ale nalézt celou řadu dalších dimenzí konfliktu surovinovou, regionálně-mocenskou, etnickou apod. Je navíc otázkou, zda lze hovořit o jednom konfliktu - Islámský stát vs. všichni okolo v různých úrovních, nebo se jedná o více samostatných a ne vždy jasně oddělitelných konfliktů. A to je právě asi největší slabinou jakékoli snahy o konceptualizaci, protože dělit současnou situaci na více paralelních konfliktů je nejen otázkou do diskuze, ale především velice problematickým úkonem stojícím na rozklíčování a oddělení přelévajícího se násilí ze strany mnoha různě zainteresovaných stran konfliktu.

V posledních (a nejaktuálnějších fázích) konfliktu jde minimálně deklaratorně o štěpení náboženské na základě sunnitsky-radikálního vymezení Islámského státu. Vzhledem k tomu, že vytvoření Islámského státu v Iráku a Levantě (Islamic State of Iraq and the Levant) v roce 2013 a následný přerod v Islámský stát či Islámský chalífát $\mathrm{v}$ roce 2014 [5] znamenalo výraznou změnu situace a orientace aktérů participujících na konfliktu, tak je vhodné z hlediska charakterizování jejich motivace a cílů vysvětlit tento vývoj v závislosti na změnách situace v obou postižených zemích. Lze tak pracovně rozdělit vývoj zapojení a cílů aktérů na dvě období - do vzniku Islámského státu a po vzniku Islámského státu, resp. před a po přelití konfliktu do sousedního Iráku. Zatímco v první fázi se většina zúčastněných zemí stavěla za protiasadovské rebely (výjimku představuje Rusko, Írán a nestátní libanonský aktér Hizballáh, stojící na straně 
syrského prezidenta Bašára Asada - viz níže), ve fázi druhé už je situace mnohem složitější. Hrozba Islámského státu se přestává líbit původním donátorům syrských rebelů a ti tak svou pomoc omezují (Saúdská Arábie, Katar), nebo dokonce proti němu aktivně vystupují a usilují o jeho zničení (USA, evropské mocnosti). Celá situace je o to složitější, že někteří aktéři deklaratorně vystupují proti Islámskému chalífátu, ale nadále jej přímo či neprrímo podporují, nebo mu jinak pomáhají v jeho přežití a udržení (Saúdská Arábie, Katar, Turecko). Do toho zde dochází k zatažení dalších aktérů do bojů, které se jich dříve netýkaly, ale nyní pro ně představují významnou bezpečnostní hrozbu (Irák, Kurdové). Popsat a vysvětlit tyto změny je tak důležitým cílem následující části.

\section{Syrská občanská válka a hlavní strany konfliktu}

Nepokoje v Sýrii, které od roku 2011 postupně přerostly do podoby občanské války, mají od počátku jednu klíčovou stranu v podobě primárního státního aktéra - režim prezidenta Bašára Asada a jeho standardní syrskou armádu. Ten má pochopitelně následující cíle - potlačit opozici, opět zcela kontrolovat celé území Sýrie a udržet se u moci. S vývojem konfliktu se cíle rozšiřují o kontrolu hranic, zabránění útokům proti náboženským a etnickým menšinám (primárně alávitům, křest’anům, Kurdům a Arménům) a zastavení islamizace země. Proti syrskému režimu a jeho cílům stojí v tehdejší době velice neforemná, roztříštěná, nesourodá a velice málo organizovaná opozice. V její silné fragmentaci lze sledovat několik základních proudů, které ovšem pojí pouze jeden cíl a tím je svržení Bašára Asada. Zcela se ale liší ve své politické orientaci a vizi budoucnosti Sýrie po odstavení prezidenta od moci. Z počátku na Západě silně akcentovaná opozice usilující o svobodné volby, ukončení autoritářského režimu a vytvoření exilové vlády uznané západními zeměmi se velice rychle rozpadá, ztrácí jakoukoli legitimitu (pokud lze vůbec hovořit o tom, že by jí kdy měla) a marginalizuje se. Další názorová skupina již akcentuje náboženský rozměr konfliktu, který staví jako souboj sunnitské většiny s vládnoucí ší'itskou menšinou. Bašár Asad a jeho vládnoucí klika totiž patří k náboženské sektě alávitů, kteří mají blíže k ší'itské verzi islámu. Tvoří asi 12 \% syrské populace, tedy výraznou menšinu v jinak sunnitské zemi. Přestože se nejedná o typické ší'ity a jsou zde nemalé názorové, zvykové, právní a náboženské rozdíly, optikou sunnitů to jsou „,všichni ší'ité, tedy náboženští nepřátelé, modláři apod.“. Cílem této názorové skupiny (nikoli ovšem monolitní) je krom svržení Bašára Asada nastolení vlády v rukou sunnitů a odstavení alávitské menšiny od moci. Největším problémem této opoziční části byla masivní fragmentace, která znemožňovala nějakou větší organizaci na politické i vojenské úrovni. V letech 2011 a 2012 byla tato část syrské opozice rozdrobena mezi stovky různých odbojových skupinek, navíc často založených na regionálním, klanovém či dokonce rodovém základě. [6] Bez nadsázky tak lze říci, že nezřídka docházelo k situaci, kdy jedna vesnice představovala jednu skupinu odporu kontrolující blízké okolí, zatímco v sousední vesnici byla skupina jiná. [7] Postupně ovšem vykrystalizovala skupina, která se s názvem Svobodná syrská armáda (Free Syrian Army) alespoň deklaratorně ujala vedoucí pozice v odboji proti Bašáru Asadovi. Přestože byla z 90 \% sunnitská [8], dokázala na svou stranu dostat rovněž některé skupiny Kurdů a Drúzů (rovněž malá sekta ší'itské větve islámu). [9] Někteří představitelé Svobodné syrské armády byli napojeni na jinak neúspěšný projekt opoziční syrské vlády pod názvem 
Syrská národní rada (Syrian National Council). Ovšem veškeré pokusy o sjednocení opozice a vytvoření uznatelné exilové vlády selhaly na vnitřních rozepřích několika frakcí a především v důsledku nástupu dalších hráčů na syrské bojiště.

Třetí významnou skupinou dle ideové orientace byly a jsou sunnitští náboženští radikálové. Ti jsou od počátku finančně i materiálně podporováni zejména ze zemí Perského zálivu, jmenovitě Saúdské Arábie, Kataru a Bahrajnu. Na této skupině se také poprvé výrazně ukázala internacionalizace celého konfliktu, protože kromě materiální podpory ze zahraničí do Sýrie začali proudit radikálové z mnoha koutů islámského světa. Předně se jedná o bojovníky z již proběhnuvších či probíhajících konfliktů v Libyi, Egypta a Iráku, dále poněkud překvapivě lze zaznamenat účast radikálů ze Severního Kavkazu (Čečenci, Dagestánci) a pak řada dobrovolníků z okolních zemí (Jordánsko, Libanon) a zemí Perského zálivu (Saúdská Arábie, Katar, Bahrajn, Kuvajt). Zvláštní kategorii tvoří bojovníci z Evropy, prričemž se z většiny jedná o přistěhovalce druhé a třetí generace radikalizující se v evropských mešitách a odjíždějících (často s romantickými představami) bojovat za své znovunalezené kulturní a náboženské kořeny. Nejdůležitějším uskupením, které dokázalo vytvořit fungující organizační strukturu a pohltit i zahraniční radikály, byla Fronta an-Nusrá, hlásící se k odkazu organizace al-Káida. V roce 2012 přitom byla velice úspěšná a viditelná i kvůli využívání teroristických technik (sebevražedné atentáty, výbuchy apod.). Z toho důvodu byla celou řadou zemí zařazena na seznam teroristických organizací. V první fázi konfliktu se jedná o klíčového hráče mezi sunnitsky radikálními skupinami, jejichž hlavním motivem a cílem je krom svržení prezidenta Asada vytvoření islámského státu saláfistického ražení. [10] Druhou významnou skupinou s dost podobnou orientací a podobným ražením je Islámská fronta, která oznámila svůj vznik až na konci roku 2013. Ideologické, náboženské, finanční a materiální napojení na Saúdskou Arábii a její spojence z Perského zálivu se přitom týká obou těchto skupin. [11] Rozdíly mezi nimi jsou spíše partikulární a jde tak spíše o klasický boj o moc mezi vưdčími osobnostmi těchto dvou organizací, stejně jako desítek dalších marginálnějších uskupení, které na syrském bojišti s podobným zázemím operují. Každopádně v současnosti jsou všechny tyto skupiny mimo pozornost z důvodu vytvoření Islámského státu, který dokonce některé pohltil a vůči jiným se vymezil.

Tím by bylo možné přejít od primárních aktérů $\mathrm{k}$ aktérům sekundárním. Jakkoli standardní rozdělení UCDP nepočítá s rozdělením primárních a sekundárních válčících stran na aktéry státní a nestátní, tak u tohoto konfliktu je patrný hlavní souboj mezi státním aktérem - Syrský režim a armáda [12] - a aktéry čistě nestátními. V př́ípadě sekundárních aktérů lze rovněž nalézt státní a nestátní strany. Ti jsou přitom jak regionální provenience, tak sestávají ze světových mocností. Na straně Asada lze nalézt dva klíčové státní spojence - Írán a Rusko. Prvně jmenovaný patří mezi klíčové partnery syrského režimu již od počátku 80 . let 20 . století a hraje důležitou roli prostředníka a pomocníka při aplikaci íránského vlivu v sousedním Libanonu a také na Palestinská území. Klíčová je především zásobovací trasa a př́istup k libanonskému Hizballáhu, radikální ší'itské (dle seznamu některých zemí také teroristické) organizaci, kterou Írán na počátku 80 . letech během libanonské občanské války fakticky založil a do dnešních dní na ni má silný vliv, a také na palestinská území v Izraeli. [13] Právě problémy na syrském území aktuálně komplikují přístup Íránu do Libanonu, což vede k zapojení Hizballáhu do konfliktu (viz níže) a zároveň větší angažovanosti samotného Íránu v konfliktu na straně Asada. Vzhledem k náboženské blízkosti se Írán logicky zapojuje 
do bojů na straně svých souvěrců jakožto hlavní a nejdůležitější stát ší'itského islámu. Naopak podpora sunnitských radikálů ze strany rovněž sunnitského palestinského Hamásu znamenalo opadnutí zájmu Íránu o podporu této teroristické organizace. Kromě udržení současného syrského režimu u moci, zajištění př́ístupu do Libanonu a udržení vlastní pozice coby vůdčí země ší ‘itů má íránské angažmá v konfliktu i další cíl - mít navrch před svým důležitým regionálním rivalem v podobě Turecka. Íránsko-turecké vztahy jsou dlouhodobě komplikované. Turci jsou kvůli své etnické blízkosti hlavním spojencem Ázerbájdžánu a Írán má na svém území silnou ázerbájdžánskou menšinu tvořící zhruba čtvrtinu populace. Obavy z iredenty podporované Tureckem jsou tak pro íránské politické elity dlouhodobě silným strašákem. Turecko je také členem NATO, až do posledních let klíčovým muslimským spojencem státu Izrael a především zemí se silnými regionálně-mocenskými ambicemi. Tím vytváří Íránu značnou konkurenci, protože ten aspiruje na vedoucí zemi v oblasti. Optikou obou zemí tedy platí, že zisk jednoho znamená ztrátu druhého. (O motivech Turecka níže.) Z těchto důvodů se Írán v konfliktu od samého počátku velice silně angažuje. Přesto se stále v této první fázi jedná o nebojovou pomoc na úrovni dodávky zbraní, munice, vojenské techniky, zpravodajských informací a politické podpory. Na syrském území již tou dobou operuje íránský vojenský personál, ale převážně pouze na úrovni poradců a zpravodajců. Jedná se tedy o sekundárního neválčícího aktéra.

Druhým klíčovým Asadovým státním spojencem je Rusko. To má poněkud jiné motivace a Sýrie pro něj není životně důležitým spojencem. Ovšem je spojencem dlouhodobým a věrným. Dokonce takovým, že Rusku dovolil vytvořit vojenskou námořní základnu v přístavu Tartús, což poskytlo Rusům důležitý př́ístup do Středozemního moře. Díky dlouhodobé relativní izolaci Sýrie na mezinárodním poli si navíc dokázalo Rusko získat v této zemi silný politický a ekonomický vliv. Kdyby Rusové nechali Bašára Asada padnout, přišli by tím o př́stup do celé oblasti Blízkého východu. [14] Tyto motivy už jsou dostatečné k tomu, aby se Rusko stalo hlavním obráncem syrského režimu na mezinárodním poli, zejména v OSN. Účinně a dlouhodobě blokuje návrhy rezolucí a dalších opatření vưči Asadovu režimu a intenzivně se snaží zabránit jakékoli cizí ozbrojené intervenci proti Asadovi, at’ už ze strany OSN či NATO. Navzdory námořní vojenské př́tomnosti se ani Rusové nezapojují do bojů, ale s velkou intenzitou zásobují syrskou armádu zbraněmi. Richard Galpin odhaduje, že vývoz do Sýrie tvoří až $10 \%$ ruského celosvětového prodeje zbraní a hodnota syrských kontraktů dosahuje úrovně 1,5 miliardy dolarů. [15] V menším množství se v Sýrii pohybují také ruští vojenští poradci, jejichž hlavním úkolem je vycvičit syrskou armádu ve využívání zbraní Ruskem dodaných. [16]

Je-li zmíněno Rusko, nelze opomenout ani druhou světovou mocnost, bráno ze studenoválečnického hlediska, Spojené státy americké. Zmínění studenoválečnického kontextu zde přitom není samoúčelné, protože USA jsou tímto viděním světa ve své politice vůči Sýrii stále značně ovlivněny. Bašár Asad jako důležitý spojenec Ruska a také dlouhodobý nepřítel státu Izrael je automaticky zařazen na seznam režimů nepřátelských (nebo alespoň méně přátelských) vůči USA. Jeho svržení s deklaratorním cílem vytvoření demokratické Sýrie bylo hlavním cílem amerických snah o podporu povstalců. Od počátku tak USA podporovaly rebely, přestože se zaměřovaly na neletální zboží - humanitární pomoc, komunikátory, balistickou ochranu, vojenskou výstroj atd. - ale dodávkám zbraní se cíleně vyhýbaly. To z toho důvodu, že Spojené státy si nebyly 
(a dodnes nejsou) zcela jisty, o jaké opoziční skupiny by se měly opríit a jakou politiku zaujmout. Do značné míry se v tom spoléhají na Turecko, tedy klíčového hráče celého konfliktu a navíc amerického blízkého spojence ze Severoatlantické aliance. [17] Zmatení, neznalost, chaos a především absence jakékoli konstruktivní vize a požadavků USA ohledně vyřešení syrského konfliktu potvrdila i slova generála Davida Petraeuse, bývalého významného vojenského představitele USA a bývalého ředitele americké CIA. Ten během své přednášky na Univerzitě obrany v Brně [18] dokázal velice přesně specifikovat, co Američané nechtějí, aby se Sýrií stalo. Nechtějí dále režim Bašára Asada u moci, ale zároveň nestojí o to, aby byla země ovládnuta islámskými radikály. Nestojí rovněž o to, aby se Sýrie rozpadla a vytvořila např. alávitskou, sunnitskou či kurdskou část. Také pro ně není prŕpustné, aby Sýrii ovládal Îrán, který představuje dlouhodobého amerického protivníka na Středním východě. Během své řeči ale nezmínil jedinou věc, kterou USA v občanskou válkou postižené Sýrii skutečně chtějí. Pouhé negativní vymezení nesměřuje $\mathrm{k}$ žádnému konstruktivnímu řešení nastalého problému a americká administrativa tak v syrském konfliktu bloudí dodnes, přestože vznik tzv. Islámského státu situaci poněkud pozměnil.

Již zde byla zmíněna důležitost aktivit Turecka v syrské občanské válce. To se snaží hrát roli regionální mocnosti, přičemž dlouhodobé nepř́liš vřelé vztahy se syrským režimem tureckou dominanci omezovaly. Naopak spojenectví Bašára Asada s Î́ránem (a také Ruskem) turecký vliv v oblasti výrazně limitoval a vedl k posilování pozice klíčového regionálního rivala v podobě Islámské republiky. Svržení Asadova režimu a nastolení režimu protureckého se tedy stalo jedním z primárních cílů Ankary. Syrský konflikt má z turecké perspektivy překvapivě i surovinovou dimenzi. Přestože sama Sýrie není z hlediska zásob ropy a zemního plynu př́lišs významný stát, zejména $\mathrm{v}$ kontextu regionu Blízkého a Středního východu, má značný potenciál coby důležitá tranzitní země. Syrským územím by mohly vést produktovody z blízkého libanonsko-izraelského šelfu [19] a samozrejmě také z oblasti Perského zálivu. Export ropy a zemního plynu z tohoto teritoria je stále životně závislý na lodní dopravě přes Hormuzskou úžinu. Závislost a zranitelnost tohoto transportního uzlu motivuje dlouhé roky k plánování vytvoření alternativní cesty ropy a zemního plynu na Západ. Území Sýrie by s napojením na tureckou infrastrukturu dále do Evropy bylo skutečně důležité. Již nyní představuje Turecko pro Evropu naprosto nepostradatelný transportní uzel pro energetické suroviny $\mathrm{z}$ oblasti Kaspického moře. $\mathrm{V}$ př́padě kontroly dopravy suroviny z oblasti Blízkého a Středního východu by turecká pozice ještě posílila, stejně jako jeho politické a ekonomické svazky s Evropou. [20] Turecko má proto eminentní zájem na ovlivnění syrského konfliktu pro vlastní užitek. K tomu využívá dvou důležitých výhod. Tou první je dobrá znalost prostředí, napojení tureckých tajných služeb na část syrských povstalců a dlouhodobě silná politická, ekonomická i vojenská pozice v regionu, tou druhou je členství v NATO. Severoatlantická aliance jednak představuje bezpečnostní záruku pro Turecko v př́padě přelití konfliktu, jednak znamená příležitost distribuce spojenecké pomoci povstalcům tak, jak Ankara uzná za vhodné. Zejména americké, ale i evropské finance, výstroj a v neposlední řadě také výzbroj jsou dodávány Turky vybraným povstaleckým skupinám. Americko-turecká spolupráce jde v současnosti dokonce až k vojenskému výcviku rebelů [21], ovšem tím, kdo identifikuje př́jemce takovéto pomoci, je většinou Ankara. Prosazování vlastních národních zájmů za peníze USA a některých evropských států NATO je pochopitelně dobrý benefit pro tureckou zahraniční politiku. 
Neméně důležitými aktéry jsou od počátku syrského konfliktu státy Perského zálivu, zejména Saúdská Arábie a Katar. Tyto dvě země stály do značné míry za vytvořením a posílením náboženské dimenze syrského konfliktu. Saúdská Arábie, jejímž státním náboženstvím je sunnitsky-radikální verze islámu, známá jako wahhábismus, je jedním z největších a nejdůležitějších sponzorů islámského radikalismu a extremismu sunnitské provenience po celém světě. Jedním z hlavních motivů saúdského království v podpoře islamistických bojůvek v zahraničí je obava před vzrůstajícím vlivem ší'itů v oblasti Blízkého a Středního východu. Jedná se o tvorbu tzv. ší'itského půlměsíce, z něhož mají sunnitské vlády nejen v regionu Perského zálivu obavy od spojenecké invaze do Iráku v roce 2003 a svržení režimu Saddáma Husajna. Ší'itský půlměsíc je pomyslné území táhnoucí se z Afghánistánu a Íránu, přes Irák do Sýrie a Libanonu. Vzrůst moci šíitů by znamenal ohrožení vnitřní bezpečnosti celé řady států, které jsou ovládány sunnity, ale zároveň mají na svém území početně významnější šíi itské skupiny. [22] To se týká především Bahrajnu, ale částečně i Kataru a Saúdské Arábie. Právě tyto země se staly klíčovými podporovateli syrských rebelů od začátku konfliktů, přičemž zde byl akcentován sektářský rozměr této podpory. Podle Financial Times [23] Katar během prvních dvou let syrské občanské války podpořil rebely částkou kolem 3 miliard dolarů a spolu se Saúdskou Arábií, která se rovněž stala důležitým finančním donátorem sunnitských bojovníků, dodával povstalcům významné množství zbraní. Roztř́ǐstěnost saúdské podpory nevykompenzovalo ani vytvoření uskupení Džaiš al-Islám (Armáda Islámu), které vzniklo v záŕí roku 2013 jako unie 43 rebelských skupin, často s radikálně-sunnitským ideologickým zázemím. [24] Saúdové tak oficiálně i neoficiálně podporují celou řadu ozbrojených opozičních skupin finančně, materiálně a také logisticky, přičemž tato podpora si našla své př́ijemce i v zárodcích tzv. Islámského státu.

Izrael je pochopitelně důležitým aktérem jakéhokoli konfliktu na Blízkém a Středním východě, protože tyto situace vždy velice citlivě vnímá z hlediska vlastní národní bezpečnosti. Izrael se do konfliktu nezapojuje přímo, protože účast židovské armády na vnitromuslimském a vnitroarabském konfliktu by mu udala úplně jinou dynamiku a hrozila by spojením všech zúčastněných právě proti státu Izrael. Na druhou stranu ale židovský stát velice pečlivě od počátku situaci monitoruje a ta také do značné míry hraje v jeho prospěch. Především je zde příležitost zbavit se dlouhodobého nepř́ítele v podobě syrského režimu, s nímž má Izrael spory o Golanské výšiny a který podporuje libanonský Hizballáh, protivníka, se kterým se izraelské bezpečnostní síly v nedávné minulosti již několikrát vojensky střetly. Na druhou stranu ale Izrael nepotřebuje na svých hranicích stát postavený na islámskyradikální věrouce, který by mohl představovat ještě větší ohrožení než pragmatický a sekulární Asad. Podle Ibrahima Fayada tak situace syrské občanské války, kdy se dva perou a třetí se směje, hraje výrazně do izraelských karet. Izraelským zájmem je udržovat tento status quo oslabující všechny jeho protivníky v oblasti. Udržování této křehké rovnováhy, kdy ani jedna strana nesmí druhou zničit, se podle Fayada snaží Izrael docílit zejména prostřednictvím ovlivňování politiky USA v regionu, protože jeho vlastní přímá intervence by byla nežádoucí a kontraproduktivní. [25]

Evropské mocnosti, konkrétně Velká Británie a Francie, se v popisované první fázi syrského konfliktu nepříliš otevřeně a veřejně angažovaly na straně protiasadovské opozice. Obě země přitom akcentovaly neletální pomoc rebelům a nejvíce se zmiňovala pomoc finanční. [26] Později ovšem vyšlo najevo to, o čem se mezi bezpečnostními 
odborníky a v mediální sféře spekulovalo, a to že obě země dodávaly rebelům kromě humanitární pomoci, financí a neletálních materiálů i zbraně. Francouzský prezident François Hollande až v polovině roku 2014 veřejně přiznal, že Francie neprrímo dodávala povstalcům, zejména těm z Svobodné syrské armády a jí přidruženým skupinkám, zbraně. [27] Velká Británie vždy oficiálně tuto možnost pouze zvažovala a zasazovala se o zrušení embarga Evropské unie pro dovoz zbraní nestátním skupinám do Sýrie. [28] V bezpečnostní a odborné komunitě ale není žádným tajemstvím, že také britské království se podílelo na dodávkách zbraní protiasadovským bojůvkám. Angažmá obou evropských mocností (především Francie) bylo patrné od samého začátku konfliktu v Sýrii, kdy obě země shodně volaly po podpoře opozice a svržení prezidenta Asada. [29] O motivaci obou zemí se dá v této době spíše spekulovat. Nejvíce se v této souvislosti hovoří o získání ekonomických příležitostí pro britské a zejména francouzské obchodní společnosti, které by měly získat př́istup na syrský trh po odstranění režimu Bašára Asada a nastolení politického režimu více otevřeného západním investicím a obchodním zájmům. [30] Nutno ovšem dodat, že evropská podpora povstalců významně klesala v kontextu náboženské radikalizace celého konfliktu. Velká Británie a Francie začaly od svých aktivit pozvolna ustupovat s tím, jak docházelo k formování zárodků tzv. Islámského státu.

Mezi méně významné státní aktéry v této části konfliktu lze ještě jmenovat okolní země, především Jordánsko, Libanon a Irák, př́ípadně kurdský autonomní region v Iráku. Jejich pozice vůči syrskému konfliktu byla formovaná především vlastními bezpečnostními riziky vyplývajícími z prŕlivu uprchlíků, přesunu zahraničních bojovníků a zbraní přes jejich území a náboženské radikalizace celého regionu. Angažovanost těchto aktérů přesto byla zpočátku velice nízká a cílila především na zabezpečení vlastních hranic a humanitární pomoc uprchlíkům. Rovněž kurdská participace na občanské válce v Sýrii byla v této fázi velice nízká, přestože v samotné Sýrii jich je mezi 2 až 2,5 miliony a tvoří tak 10 až 15 procent populace. Kurdové ale nebyli masově součástí ani protiasadovského odboje, ani vládních sil potlačujících rebelii. Kurdská území v Sýrii vyhlásila neutralitu, do bojů př́liš nezasahovala a nebyla ani napadána. To vše se změnilo až s nástupem Islámského státu, přestože Kurdové byli napadáni i dalšími islamistickými skupinkami. [31]

V př́padě nestátních aktérů je kromě výše uvedených opozičních skupin třeba uvést zejména roli libanonské organizace Hizballáh. Jedná se o radikální ší'itskou organizací vzniklou v průběhu libanonské občanské války na začátku 80. let a fakticky vytvořenou íránskými Revolučními gardami. Je tak nejen dlouhodobým íránským spojencem (či dokonce nástrojem), ale také spojencem syrské strany Baas a Bašára Asada. Právě přes syrské území je Hizballáh zásoben íránskými a syrskými zbraněmi, financemi a celou řadou dalšího materiálu potřebného pro zabezpečení aktivit této skupiny. Dlouhá desetiletí tak lze hovořit o klíčové ose Írán - Sýrie - Hizballáh (či Teherán - Damašek - Biká), která do značné míry určovala a určuje bezpečnostní dynamiku v regionu. [32] Udržení režimu Bašára Asada a jeho kontrola syrského území je proto životním zájmem Hizballáhu, kterému reálně hrozí odříznutí a izolace. $Z$ toho důvodu se bojovníci Hizballáhu aktivně zapojují do syrského konfliktu od počátku roku 2012, deklaratorně a otevřeně od roku 2013, přičemž obsazují, čistí a kontrolují oblasti na jihozápadě Sýrie, především v regionu al-Qusa'ír, sousedících s Libanonem. [33] Kvůli tomu mají standardní syrské ozbrojené síly volné ruce zasahovat v jiných regionech, aniž by se musely 
strachovat o bezpečnost v regionech kontrolovaných Hizballáhem. Zapojení této libanonské skupiny do bojů v Sýrii jen zdůrazňuje náboženskou dimenzi konfliktu, protože sunnité z řad protivníků zdůrazňují ší'itské zázemí organizace. Hizballáh se na druhé straně alespoň rétoricky snaží nestavět své zapojení do konfliktu na ší'itsko-sunnitském základě, protože by to způsobilo značné pnutí na vnitrolibanonské úrovni. O tom ostatně svědčí veřejná prohlášení generálního tajemníka Hizballáhu Hassana Nasralláha, v nichž syrské rebely označuje za odpadlické teroristy, nejsou to muslimové, ale vrazi, kteří vraždí mnohem více sunnitů než ší'itů a křest'anů, a pro Hizballáh je důležité chránit proti těmto lidem svou zem a všechny mírumilovné a civilizované lidi v okolí. [34]

\section{Islámský stát a proměna motivace a zapojení aktérư}

Do dynamiky syrského konfliktu výrazně zasáhlo vytvoření tzv. Islámského státu z června roku 2014, přestože skupina jej formující operovala na syrsko-iráckém teritoriu již dř́ve, jen pod jinými názvy. Islámský stát, známý také pod zkratkou IS, nebo ISIS (Islamic State of Iraq and Syria) či ISIL (Islamic State of Iraq and the Levant), př́padně pod arabským názvem Dá'iš či Dá'eš (z arabské zkratky slov ad-Dawlat al-Islámíja ti al-Irák wa š-Šám - Islámský stát v Iráku a na Blízkém východě), vznikl při přelití konfliktu do sousední sunnitské části Iráku a mocenském upevnění několika islámsky-radikálních skupin na území těchto dvou států. Politickým a duchovním vůdcem Islámského státu (dále jen IS) se stal Abú Bakr Baghdádí - Iráčan, který se sám jmenoval do pozice chalífy tohoto kvazistátního uskupení. Geneze, fungování a vnitřní složení Islámského státu jsou tématy samy o sobě a není cílem tohoto textu je detailněji rozebírat, protože by to znamenalo významné překročení limitů tohoto textu. Každopádně at' už je centralizace, hierarchizace a správa IS v mnohém diskutabilní, je třeba s ním počítat jako se zcela novým aktérem, který výrazně ovlivnil chování a cíle ostatních aktérů konfliktu na území Sýrie a Iráku. Sám IS se přitom deklaratorně vymezuje vůči centrálním vládám v Damašku a Bagdádu, přičemž usiluje o svržení těchto vlád, plné kontrole dobytého území a další územní expanzi a vytvoření nábožensky čistého (radikálního) sunnitského státu. Velice tvrdé podmínky pro obyvatele na jím kontrolovaném území, náboženské a etnické čistky a masakry spolu s agresivními výboji, rekrutováním zahraničních radikálů nejen z muslimských zemí a podporou islámského radikalismu a terorismu, to vše dělá z IS silně akcentovanou hrozbu nejen pro samotný syrský a irácký stát, ale i pro okolní země, regionální stabilitu a státy, z nichž do oblasti odchází dobrovolníci bojovat za hodnoty a zájmy IS.

Vznik IS výrazně změnil postoj a chování USA vůči syrskému a nyní i iráckému konfliktu. Přelití války do sousedního Iráku, za nějž se Spojené státy stále cítí zodpovědně, vedlo k americké podpoře irácké standardní armády, která se krom kurdských bojovníků (pešmergů) stala hlavním protivníkem na tzv. východní frontě bojiště IS. Její počáteční neúspěchy a prohry, které vedly až k ohrožení hlavního města Bagdádu, si na USA vynutily mnohem větší angažovanost v konfliktu. Rovněž brutální vražda amerického novináře Jamese Foleyho (a celé řady dalších západních rukojmích) vzbudila v americkém veřejném mínění a politické sféře vlnu pobouření a odhodlání toto barbarské chování zastavit a viníky potrestat. V záŕí roku 2014 pak Spojené státy ústy svého 
prezidenta Baracka Obamy vyhlásily za svůj cíl zničení IS a zlikvidování této teroristické hrozby pomocí letecké kampaně na syrském a iráckém území. [35] Pod vedením USA tak vzniká koalice států, které používají svého letectva k útokům na cíle IS, přičemž jejími členy jsou krom Spojených států také Bahrajn, Jordánsko, Katar, Saúdská Arábie a Spojené arabské emiráty (více o těchto státech viz níže). Nutno ovšem dodat, že celkově má tzv. koalice proti IS na 62 zemí, přičemž většina z nich podporuje protivníky IS finančně či humanitární pomocí. [36] Kromě letecké kampaně se USA potýkají s IS také na pozemním bojišti, a to především dodávkami zbraní, techniky, financí a dalšího materiálního zajištění standardní irácké armádě a kurdským bojovníkům v Sýrii a Iráku. Př́ítomné jsou zde ale také jednotky amerických speciálních sil, které vyvíjejí především poradenskou činnost. Ze stejného důvodu jsou na tomto místě dislokovány i síly kanadské, britské a další.

Americkým cílem číslo jedna je zničení IS, přičemž se soustředí na leteckou kampaň a podporu irácké armády, kurdských bojovníků a řady syrských opozičních skupin. Jakékoli pozemní angažmá ale USA stále odmítají. Nicméně touto pozicí se Spojené státy fakticky dostaly na stejnou stranu bojové linie jako režim Bašára Asada a Írán. Přesto prezident Obama nadále zavrhuje vytvoření jakéhokoli spojenectví s Asadem, nadále trvá na jeho sesazení a budoucnost Sýrie vidí pouze bez současného syrského prezidenta. [37] Za tímto nesmiřitelným postojem lze vnímat silný turecký tlak (viz níže), protože Turecko v pozici klíčového amerického spojence v oblasti stále trvá na svržení Bašára Asada jako na klíčovém cíli spojeneckého angažmá v Sýrii v boji proti IS. Na druhou stranu, pokud by se Spojené státy rozhodly Asada nakonec podpořit, otevřelo by jim to možnost zlepšit vztahy s Íránem a posílit vlastní pozici v oblasti. Tato strategická až geopolitická dilemata do značné míry určují americkou schizofrenní pozici v současném konfliktu s IS.

Druhým nejdůležitějším vnějším aktérem v boji proti hrozbě IS je bezesporu Írán. Ten výrazně posílil vlastní angažmá, které se nyní neomezuje pouze na syrské bojiště a podporu Asadovy armády, ale expandoval na bojiště irácké. Teherán je hlavní spojenec irácké ší'itské vlády a rebely z IS má doslova za svými hranicemi. Dá'eš představuje pro Írán aktuálně největší a nejakcentovanější bezpečnostní hrozbu, přičemž je primárním íránským zájmem IS zničit a ochránit (posílit) irácký a syrský stát v boji proti němu. [38] Írán přitom kromě materiální a finanční podpory irácké armády a kurdských bojovníků do konfliktu přispívá i vlastními vojenskými silami. Vytváří vlastní leteckou kampaň, íránští vojenští poradci, zejména ti ze speciálních útvarů íránských Revolučních gard [39], trvale spolupracují na operační úrovni s iráckou armádou a bylo zaznamenáno i přímé zapojení íránských vojáků do bojů. Na iráckém bojišti přitom nechybí íránské vojenské špičky, včetně legendárního generála Qásema Soulejmáního, který zde vede speciální operace. [40] Íránská motivace i cíle se tak v průběhu konfliktu s př́ichodem IS př́liš nezměnily a stále se jedná zejména o udržení Bašára Asada u moci, udržení spojení s libanonským Hizballáhem, vítězství nad regionálními rivaly Tureckem a Saúdskou Arábií a posílení ší'itského prvku v oblasti. K nim lze ovšem přidat ještě jeden, nepř́iliš výrazný a málo akcentovaný - možnost sblížení se Spojenými státy. Dle logiky - nepř́itel mého nepř́itele je můj př́tel - dochází k tomu, že USA a Írán se dostávají na stejnou stranu v konfliktu s IS. V kontextu probíhajících jednání o íránském jaderném programu a zrušení ekonomických sankcí vůči této zemi ze strany Spojených států a Evropské unie pak může být íránské angažmá v Sýrii a Iráku zajímavou možností, jak ovlivnit jejich výsledek. 
Turecká pozice je v konfliktu se vznikem IS ještě důležitější. Turecko se pochopitelně vymezuje vůči IS, protože se jedná o problematického, nestabilního a nevypočitatelného aktéra, který staví na úplně jiných principech než Ankara. Skrze IS nemůže rozvíjet žádný svůj plán a dosáhnout výše vytyčených cílů, protože to je jednak politicky neprůchodné, jednak technicky nemožné. Na druhou stranu ale Turci nechtějí připustit vítězství Bašára Asada a Íránu stejně jako ztratit vliv mezi opozičními skupinami. Turecké bezpečnostní dilema se znásobilo s tím, jak do konfliktu byli ve větší míře zataženi Kurdové. Ti čelí útokům nejen na iráckém území, kde byli nuceni hájit vlastní autonomní území, ale především v Sýrii, přičemž symbolem bojů Kurdů proti IS snažícím se etnicky jím ovládané oblasti vyčistit se stalo město Kobani. [41] Na tomto prŕkladu lze nejlépe demonstrovat problematickou tureckou pozici. Ankara byla pod silným mezinárodním tlakem, aby Kurdům bojující za záchranu vlastního města a ušetření obyvatel etnických čistek ze strany IS pomohla, nebo alespoň umožnila průjezd kurdským pešmergům přes turecké území. Toho se ale Ankara velice dlouho zdráhala a dokonce byla nucena násilím potlačovat protesty na vlastním území, kdy turečtí Kurdové vyjadřovali nespokojenost s jednáním turecké vlády. [42] Nakonec ale Turci umožnili na konci ř́ijna roku 2014 průjezd kurdských sil do Kobani, což znamenalo obrat v dosavadních bojích a postupné odrážení útočníků z IS. [43] Turecká motivace k zaujetí takovéto pozice je dána vlastními bezpečnostními zájmy. Turecko má dlouhodobé problémy se separatistickými tendencemi kurdské menšiny na svém území. Podpora pro Turky tolik problémových Kurdů by se časem mohla obrátit proti nim samotným. Obavy z toho, že dnes vyzbrojí a podpoří Kurdy, aby ti proti nim zítra tyto zbraně obrátily, jsou v současnosti hlavním bezpečnostním dilematem Ankary v konfliktu na sousedních územích. Vítězství Kurdů v Sýrii a jejich nejasná budoucnost doslova hrozí vytvořením další kurdské autonomie (po autonomii irácké) a znovuaktivování kurdského protitureckého boje za vizi samostatného a velkého Kurdistánu. Vybalancování kurdské otázky (mezinárodním tlakem vynucená podpora proti IS vs. oslabování kurdských autonomizačních snah), redistribuce zejména americké pomoci umírněným syrským opozičním skupinám, snaha o svržení Bašára Asada, poškození pozice Íránu a naopak zisk kontroly nad syrským územím jsou v současnosti hlavními motivy a cíli tureckého angažmá v konfliktu. Množství a v určitých prrípadech dokonce protichůdnost těchto cílů spolu se silnou tureckou angažovaností v konfliktu rozhodně neskýtají mnoho příležitostí pro jeho brzké ukončení a vyřešení plně k turecké spokojenosti. Turecko je tak aktér nejen velice významný, ale z hlediska řšení konfliktu také silně problémový.

Ruské cíle se se vznikem IS př́lliš nezměnily. Rusko je stále na mezinárodním poli nejdůležitějším spojencem Bašára Asada a snaží se hrát roli zprostředkovatele mírových jednání mezi ním a povstalci. Jak poznamenává Břetislav Tureček [44] veškerá snaha o normalizaci situace, zprostředkování jednání a domluvení jakéhokoli prríměří či klidu zbraní je dlouhodobě značně problematická, ne-li nemožná z důvodu silné roztř́íštěnosti syrské opozice a exilové vlády, která nemá prakticky žádnou legitimitu ani schopnost reprezentovat desítky bojových uskupení operujících na syrském území. Rusové také začali více akcentovat hrozbu, kterou s sebou přináší zapojení zahraničních bojovníků do bojů za IS. Prakticky od počátku zde lze nalézt tzv. severokavkazskou stopu, tedy bojovníky zejména z oblasti Čečenska a Dagestánu, přičemž stejně jako v případě Evropy (viz níže) jejich př́ípadný návrat způsobuje bezpečnostní obavy v jejich domácí zemi. [45] 
Výraznější proměnu zažily s růstem moci IS země Perského zálivu, pro něž již nebylo nadále politicky udržitelné sunnitsky-radikální povstalce oficiálně podporovat. IS se svým extremismem, problematickým chováním a značnou agresivitou vytvářejí prakticky neřízenou střelu, kterou ani mecenáši z Perského zálivu nedokáži kontrolovat. V boji proti síle, která začala výrazně ohrožovat sousední Irák, je navíc z náboženských a politických důvodů nezbytné, aby se jej účastnily státy představující hlavní autority v sunnitském světě. Oficiálně jsou tak Saúdská Arábie, Katar a další státy součástí koalice útočící na pozice IS ze vzduchu a snažící se o zlikvidování tohoto kvazistátního útvaru. Neoficiálně ovšem z těchto zemí stále tečou IS finance od mocných a bohatých mecenášů, př́ípadně bojovný i nebojový materiál, původně neurčený IS, který ale v jeho rukách nakonec končí. [46] Z toho vyplývá, že také pozice států Perského zálivu je silně schizofrenní, kdy se Saúdská Arábie, Katar či Bahrajn př́mo účastní náletů na pozice IS, ovšem na druhou stranu sunnitské radikály stále v menší míře podporují s cílem oslabit regionální vliv Íránu, svrhnout režim Bašára Asada a zabránit posílení tzv. ší’itského půlměsíce. [47]

Oproti tomu pozice Izraele se vůči syrskému konfliktu př́liš nezměnila. Jak připustil izraelský velvyslanec v České republice Gary Koren [48], Izraeli fakticky vyhovuje současný stav, kdy se jeho dlouhodobí neprrátelé oslabují mezi sebou navzájem, takže se veškerá jejich pozornost věnuje občanské válce v Sýrii a IS, nikoli právě Židovskému státu. Vybalancování konfliktu tak, aby nedošlo k ohrožení Izraele a vítězství islámských radikálů (at' už v IS, nebo posílením libanonského Hizballáhu) je podle Korena klíčovým úkolem izraelských bezpečnostních snah. Také zmíněný Hizballáh s př́íchodem IS př́liš nezměnil svou pozici a cíle. I nadále aktivity této libanonské skupiny vedou především k udržení Bašára Asada u moci v sousední Sýrii, zachování spojení na Írán a k podpoře ší'itských souvěrců.

Poněkud jinak je na tom izraelský soused Jordánsko, které se z původních opatrných opatření cílících na řešení vlastních humanitárních problémů s uprchlíky dostalo až do koalice provádějících nálety na pozice IS. Počáteční váhavé zapojení se ale změnilo v usilovnou snahu o zničení IS poté, kdy došlo k sestřelení jednoho jordánského pilota a jeho následné expresivní upálení zaživa coby zajatce v kleci. Video z tohoto hrůzného činu detailně propracované v rámci multimediální propagandy IS doslova oběhlo svět a vedlo k tvrdým vyjádřením jordánských politických a vojenských představitelů požadujících zničení IS a pomstění vlastního pilota. [49] Také Irák se ze své původní pozice nervózního pozorovatele syrské občanské války dostal do úrovně hlavního bojovníka proti IS, když došlo k přelití konfliktu na jeho území (nutno dodat, že konflikt zde od roku 2003 zcela nevymizel). Dostal se tak do první linie bojů, kterou zabezpečují jednotky pravidelné irácké armády ve spolupráci jak s Američany a jejich spojenci, tak s Íránem. Po prvotním šoku způsobeným expanzí IS se Iráčanům podařilo sunnitské radikály zastavit a částečně zatlačit zpět, ovšem bezpečnostní situace blízko frontové linie irácké Sámarry či Tikrítu je stále velice kritická a Bagdád tak nekontroluje velkou část svého území obývaného sunnity. Nechvalně proslulá nízká kvalita irácké armády přitom neskýtá př́liš šancí na nějaký výrazný pokrok v boji proti IS bez přispění zahraničních spojenců. Navíc v důsledku použití většiny vlastních bezpečnostních sil na boj s IS na severozápadě země a jejich stažení z jižních částí Iráku dochází ke zhoršení situace také tam. Došlo tak k obnovení bezpečnostních rizik, která již byla na jihu téměř vymýcena. Dochází k častějším útokům na zahraniční pracovníky, jejich únosům, poškozování ropné infrastruktury, 
bujení organizovaného zločinu a mezikmenovému násilí. [50] Irák se tak opět dostává velice blízko k hranici občanské války či celého zhroucení země, přičemž jeho celistvost a bezpečnost do značné míry závisí na externích silách.

Přestože se ohrožení bojovými aktivitami IS př́mo nedotýká evropského kontinentu, pro řadu evropských států jeho geneze znamenala vytvoření závažné bezpečnostní hrozby. Původní aktivní angažmá Velké Británie a Francie při prosazování svých zájmů v syrském konfliktu se proměnilo na pasivní obranu vůči vlastním občanům jedoucím za IS do Sýrie a Iráku bojovat. Evropské státy v současnosti čelí v souvislosti s IS hrozbě v podobě bojovníků vlastnících britské, francouzské, belgické či německé pasy a občanství. Občané těchto zemí je v posledních dvou letech ve velkém opouští, aby se zapojili do bojů, přičemž podle francouzského premiéra Manuela Vallse se jedná o zhruba 3000 osob. Zároveň ale odhaduje jejich nárůst do poloviny roku na úroveň 5000 a pred koncem roku 2015 by Evropanů bojujících za zájmy IS mohlo být až 10 000. [51] Nad Evropou se logicky vznáší strašák opakování tzv. afghánského scénáře, kdy se do Sověty okupovaného Afghánistánu v 80. letech sjeli bojovníci z prakticky celého muslimského světa, získali zde vojenský výcvik, zkušenosti a ideologickou (náboženskou) indoktrinaci. Po skončení konfliktu se vrátili do svých domovských zemí, což často vedlo k nárůstu náboženského radikalismu a násilí v těchto státech a vytvoření struktury pro pozdější globální teroristickou organizaci al-Káida. Obava z toho, že se něco podobného stane Evropě po návratu tisíců jejích občanů z IS, je aktuálně hlavním faktorem určujícím evropskou pozici vůči konfliktu na území Sýrie a Iráku. Evropa tak postupně stahuje svou původní podporu syrským rebelům a více se zaměřuje na vlastní bezpečnostní opatření vůči vzrůstajícímu islámskému radikalismu na svém území. Její aktivita se omezuje především na finanční pomoc boji proti IS, když v únoru roku 2015 oznámila EU uvolnění prostředků na tuto činnost v hodnotě jedné miliardy Eur. Další peníze pak mají jít humanitární krizí postiženému Libanonu a dalším projektům tlumícím válečné následky v oblasti. [52]

\section{Závěr}

Občanská válka v Sýrii a konflikt s tzv. Islámským státem představují v současnosti jeden z největších problémů celosvětové bezpečnosti, přestože se jedná do určité míry o pouhou regionální záležitost. Hlavním problémem bránícím vyřešení celé situace je značná internacionalizace konfliktu a skutečnost, že se do něj zvnějšku zapojují nejen významní regionální hráči typu Turecka, Íránu a Saúdské Arábie, ale také světové mocnosti jako USA, Rusko a evropské státy. Množství těchto externích aktérů, značná roztřrištěnost syrské opozice vưči režimu Bašára Asada, slabost syrského a iráckého státu a především silná nesourodost a často protichůdnost zájmů hájených každým jednotlivým aktérem konfliktu zpo̊sobují jeho eskalaci, znepřehlednění a hlavně omezení vyhlídky na jeho rychlé řešení. Světová mocnost Spojené státy stále neví, jakou pozici vůči konfliktu v Sýrii zaujmout, zda podpořit Bašára Asada v boji proti IS, jestli se více vojensky angažovat, má-li se nadále opírat o tureckého spojence a jak zamezit šíření islámského radikalismu v oblasti. Obdobná dilemata řeší i Evropské mocnosti, kterým aktuálně hrozí největší nebezpečí z radikalizace vlastních obyvatel a jejich návratu ze syrského bojiště. Rusko zejména na politické úrovni dělá vše proto, aby podrželo svého dlouholetého 
syrského spojence a zamezilo aktivitám kavkazských rebelů v oblasti, kteří samotní představují bezpečnostní problém pro Ruskou federaci. [53] Role Turecka a Íránu jsou motivovány vzájemným regionálním soupeřením, balancováním síly kurdských bojovníků a obavami z růstu sunnitského radikalismu v oblasti. Motivy a cíle okolních arabských zemí navíc trpí jistou schizofrenií, kdy se na jedné straně snaží zlikvidovat nevyzpytatelný a nebezpečný IS, na druhou stranu se snaží vyvážit posilování ší'itského elementu v regionu.

V takovémto prostředí pak existence a přežívání Islámského státu není ničím překvapivým, jakkoli by toto uskupení bylo možné rychle a efektivně zlikvidovat, pokud by $\mathrm{k}$ tomu byla všeobecná vůle a shoda celého mezinárodního společenství bez partikulárních národních zájmů participujících aktérů. V současném rozložení sil a zájmů ale zánik IS a uklidnění konfliktu na území Sýrie a Iráku nelze př́liš brzy očekávat.

\section{Poznámky k textu a použitá literatura}

[1] Uppsala Conflict Data Program. Definitions [on-line]. Department of Peace and Conflict Research, Uppsala University, Dostupné z: http://www.pcr.uu.se/research/ucdp/definitions/

[2] DYČKA, Lukáš. 2012. Typologie aktérů v konfliktech., Politologická revue, roč. 2012, č. 1, s. 73-93. Praha.

[3] SMOLÍK, Josef, ŠMÍD, Tomáš a kol. 2010. Vybrané bezpečnostní hrozby a rizika 21. století, Brno: Mezinárodní politologický ústav Masarykovy univerzity. ISBN 978-80-210-5288-8; MIODOWNIK, Dan and BARAK, Oren (eds.). 2013. Nonstate Actors in Intrastate Conflicts. Pensylvania: Penn Press, ISBN 978-0-8122-4543-1; MOLLER, Bjorn. 2009. The Somali Conflict: The Role of External Actors [on-line]. DIIS Report 2009:03, Dostupné z: http://subweb.diis.dk/graphics/Publications/Reports2009/ DIIS_report_2009_03_Somali_conflict.pdf; GALTUNG, Johan. Theories of Conflict: Definitions, Dimensions, Negations, Formations, TRANSCEND University Press.

[4] RADĚJ, Tomáš. 2011. Jasmínová nákaza [on-line]. Centrum pro bezpečnostní a strategická studia. Dostupné z: http://www.cbss.cz/expertni-komentar/jasminova-nakaza/

[5] Důležitým milníkem syrského konfliktu je krom vyhlášení Islámského státu především přelití násilí do sousedního Iráku a okupace sunnitských území v tomto státě. Jednak nastalá situace zatáhla do konfliktu a problémů další státní útvar - Irák, jednak dotlačilo k přehodnocení situace Spojené státy, které od invaze do této země v roce 2003 Irák stále považují za svou odpovědnost a teritorium předního národního zájmu. Více ke genezi Islámského chalífátu MORTADA, Radwan. 2014. What does ISIS'declaration of a caliphate mean? [on-line]. al-Akhbar.com. Dostupné z: http://english.al-akhbar.com/node/20378

[6] Vícek syrské fragmentaci opozice viz KHAN,Azmat. 2011.Q\&A:ACloser Lookat Syria’s Fragmented Opposition [on-line]. PBS.org. Dostupné z: http://www.pbs.org/wgbh/pages/frontline/foreign-affairs-defense/ syria-undercover/a-closer-look-at-syrias-fragmented-opposition/ či SAMAAN, Jean-Loup. 2013. Syria 's Fragmented Opposition [on-line]. Al-Monitor, Dostupné z: http://www.al-monitor.com/pulse/originals/ 2013/04/syria-fragmented-opposition-history-khatib.html\#

[7] Tento stav do značné míry funguje stále, přestože byl poněkud zastíněn vyhlášením Islámského státu. Dobře lze celou fragmentaci a situaci na syrském bojišti vidět na interaktivní mapě katarského zpravodajského serveru Al-Džazíra, viz http://www.aljazeera.com/indepth/interactive/2013/07/20137188552345899.html

[8] Turkish Weekly, 8. 10. 2011. Syrian Opposition Call for No-Fly Zone [on-line]. Dostupné z: http:// www.turkishweekly.net/news/124717/syrian-opposition-call-for-no-fly-zone.html

[9] DEHGHANPISHEH, Babak. 2013. Syria's Druze minority is shifting its support to the opposition [on-line]. The Washington Post. Dostupné z: http://www.washingtonpost.com/world/ middle_east/syrias-druze-minority-is-shifting-its-support-to-the-opposition/2013/02/07/ 9e3f52c6-6d5d-11e2-ada0-5ca5fa7ebe79 story.html

[10] IGNATIUS, David. 2012. Al-Qaeda affiliate playing larger role in Syria rebellion [on-line]. The Washington Post. Dostupné z: http://www.washingtonpost.com/blogs/post-partisan/post/al-qaeda-affiliate -playing-larger-role-in-syria-rebellion/2012/11/30/203d06f4-3b2e-11e2-9258-ac7c78d5c680_blog.html

[11] DARK, Edward. 2013. Syrian FSA fades in shadow of Saudi-backed opposition front [on-line]. $\overline{A l}$-Monitor. Dostupné z: http://www.al-monitor.com/pulse/originals/2013/12/syria-fsa-islamic-front-geneva-ii-jarba.html\# 
[12] Zde je nutné doplnit, že i na straně syrského režimu se vyskytuje několik nestátních aktérů, většinou nejrůznějších vigilantistických skupin, které s tichou podporou či vědomím režimu bojují proti povstalcům. Mezi nejznámější patr̂̌i nechvalně proslulá milice Šabíha.

[13] KRAUS, Josef. 2010. Komparace strategie íránské podpory terorismu na př́íkladu Hamásu a Hizballáhu [on-line]. Obrana a strategie, roč. 10, č. 2, Dostupné z: http://www.defenceandstrategy.eu/cs/ aktualni-cislo-2-2010/clanky/komparace-strategie-iranske-podpory-terorismu-na-prikladu-hamasu-a -hizballahu.html\#.VMkppETvolI

[14] AL-MARHOUN, Abdul Jalil. 2014. The story of Syrian-Russian relations [on-line]. Middle-East Monitor. Dostupné z: https://www.middleeastmonitor.com/articles/europe/9631-the-story-of-syrian -russian-relations

[15] GALPIN, Richard. 2012. Russian arms shipments bolster Syria's embattled Assad [on-line]. BBC.co.uk. Dostupné z: http://www.bbc.co.uk/news/world-middle-east-16797818

[16] BORGER, Julian. 2012. Russian military presence in Syria poses challenge to US-led intervention [on-line]. The Guardian, Dostupné z: http://www.theguardian.com/world/2012/dec/23/ syria-crisis-russian-military-presence

[17] Diskuze s Ibrahimem Fayadem na přednášce Centra pro lidská práva a demokratizaci, 5. 12. 2013.

[18] Přednáška Davida Petraeuse, Univerzita obrany, Brno, 19. 9. 2013.

[19] Více viz: KRHOVSKÁ, Hana. 2014. Conflict Resolution in the Disputes over Resources in the Eastern Mediterranean: The Case of Israel and Lebanon [on-line]. (Diplomová práce). Brno: Fakulta sociálních studií, Masarykova univerzita.

[20] SOULEIMANOV, Emil a Josef KRAUS. Turkey: An Important East-West Energy Hub. Middle East Policy, Washington: Middle East Policy Council, 2012, roč. 19, č. 2, s. 157-168.

[21] NAVIS, Sean. 2015. US And Turkey's Competing Interests In Syria: Fighting ISIS Or Fighting Assad? [on-line]. MintPress News. Dostupné z: http://www.mintpressnews.com/us-and-turkeys-competing -interests-in-syria-fighting-isis-or-fighting-assad/203130/

[22] Middle East Quarterly. 2005. King Abdullah II: „Iraq is the Battleground - the West against Iran [on-line]. Vol. XII, No. 2 Spring 2005, Dostupné z: http://www.meforum.org/688/king-abdullah -ii-iraq-is-the-battleground

[23] Financial Times. 3. 6. 2013. Qatar bankrolls Syrian revolt with cash and arms [on-line]. Dostupné z: http://goo.gl/89646D

[24] The Guardian. 7. 11. 2013. Syria crisis: Saudi Arabia to spend millions to train new rebel force [on-line]. Dostupné z: http://www.theguardian.com/world/2013/nov/07/syria-crisis-saudi -arabia-spend-millions-new-rebel-force

[25] Diskuze s Ibrahimem Fayadem, viz ref. 17.

[26] BBC. 10. 8. 2012. Syria conflict: UK to give extra £5m to opposition groups [on-line]. Dostupné z http:// www.bbc.com/news/uk-19205204

[27] MABUT, Pierre. 2014. France admits it directly supplied arms to Syrian "rebels" [on-line]. WSWS. org, Dostupné z: http://www.wsws.org/en/articles/2014/08/27/frsy-a27.html

[28] The Guardian. 28. 4. 2013. UK forces EU to lift embargo on Syria rebel arms [on-line]. Dostupné z: http://www.theguardian.com/world/2013/may/28/uk-forced-eu-embargo-syria-rebel-arms

[29] Zde stojí za zmínku i skutečnost, že Francie byla první zemí na světě, která veřejně obviňovala režim prezidenta Asada z užití chemických zbraní a volala v tomto př́ípadě po použití síly k potrestání viníka. SEDHAIN, Pramod Raj. Syrian Conflict: The Key International Interests [on-line]. Dostupné z: http:// www.academia.edu/4355411/Syrian_Conflict_The_Key_International_Interests

[30] IRISH, John. 2012. France eyes Middle East influence, image with Syria gamble [on-line]. Reuters.com. Dostupné z: http://www.reuters.com/article/2012/11/19/us-syria-crisis-france-idUSBRE8AE0K620121119

[31] NAZEMROAYA, Mahdi Darius. 2014. The War in Western Kurdistan and Northern Syria: The Role of the US and Turkey in the Battle of Kobani [on-line]. GlobalResearch.ca, Dostupné z: http://www.globalresearch.ca/ the-war-in-western-kurdistan-and-northern-syria-the-role-of-the-us-and-turkey-in-the-battle-of-kobani/5413303

[32] Více viz KRAUS, Josef. 2010. Komparace strategie íránské podpory terorismu na př́kladu Hamásu a Hizballáhu, ref. 13. a KRAUS, Josef. 2014. Íránský státni terorismus: Od Chomejního po Ahmadínežáda, Brno: CDK. ISBN: 978-80-7325-342-4.

[33] Al Arabiya, 17. 2. 2013. Hezbollah fighters, Syrian rebels killed in border fighting [on-line]. Dostupné z: http://english.alarabiya.net/articles/2013/02/17/266843.html

[34] Jednu z nejslavnějších řečí Hassana Nasralláha s doprovodnými záběry a hudební dramatizací je možné zhlédnout na https://www.youtube.com/watch?v=2ZuNg3cm1PE 
[35] HUDSON, David. 2014. President Obama: "We Will Degrade and Ultimately Destroy ISIL" [on-line]. The White House Blog, Dostupné z: https:/www.whitehouse.gov/blog/2014/09/10/ president-obama-we-will-degrade-and-ultimately-destroy-isil

[36] DRENNAN, Justin. 2014. Who Has Contributed What in the Coalition Against the Islamic State? [on-line]. Foreign Policy. Dostupné z: http://foreignpolicy.com/2014/11/12/who-has-contributed -what-in-the-coalition-against-the-islamic-state/

[37] The Daily Mail, 16. 11. 2014. Obama rules out alliance with Syria's Assad against IS [on-line]. Dostupné z: http://www.dailymail.co.uk/wires/afp/article-2836487/Obama-rules-alliance-Syrias-Assad-against-IS.html

[38] Rozhovory autora s politology univerzity Al-Mustafa v Qomu, Írán, únor 2015.

[39] Sepáh-e Pásdárán-e Enqeláb-e Islámi - doslova Armáda strážců islámské revoluce. Jsou známé také pod názvy Sepáh či Pásdárán nebo pod zkratkou IRGC (The Islamic Revolutionary Guard Corps). Revoluční gardy byly založené ajatolláhem Chomejním ihned po tzv. Islámské revoluci v roce 1979 k ochraně nově nastoleného islámského pořádku. Postupně se ale z nich vytvořila plnohodnotná paralelní armáda plnící celou řadu speciálních funkcí uvnitř Íránu i v zahraničí. Více viz KRAUS, Josef. Iranian Revolutionary Guard Corps and Their Influence on the Iranian Government, Military and Economy. In: Proceedings International Scientific Conference Strategies XXI: The Complex and Dynamic Nature of the Security Environment, National Defence University - Centre for Defence and Security Studies, 2014, p. 171-175. ISSN 2285-8318.

[40] Qásem Soulejmání je vrchním velitelem speciálních sil Revolučních gard pod názvem Al-Quds (arabské a perské označení Jeruzaléma). Jeho fyzická přítomnost na bojišti je v Íránu často zmiňována a Soulejmání je dlouhodobě vnímán jako národní hrdina, který musí být prrítomen u všech důležitých íránských vojenských operací.

[41] Obléhání a dobývání města Kobani, nacházejícího se blízko syrsko-turecké hranice se stalo jednou z mediálně nejsledovanějších bitev etnických Kurdů proti agresorům z IS. Masivní boje, útoky na civilní obyvatelstvo a silný mezinárodní tlak na Turecko, aby umožnilo kurdským bojovníkům použít vlastní území k přesunu sil a materiálu na podporu dobývaného města, to byly nejdůležitější prvky od poloviny roku 2014 obléhaného Kobani.

[42] Během potlačování těchto protestů bylo dokonce 12 lidí usmrceno. BBC, 8. 10. 2014. Kobane: Air strikes help Syria town curb IS [on-line]. Dostupné z: http:/www.bbc.com/news/world-middle-east-29526783

[43] Syrian Observatory for Human Rights, 31. 10. 2014. More than 20 vehicles enter the city of Kobani [on-line]. Dostupné z: http://syriahr.com/en/2014/10/more-that-20-vehicles-enter-the-city-of-kobani/

[44] TUREČEK, Břetislav. Je Blízký východ spásou Ruska? Lidové noviny 24. 1. 2015.

[45] SOULEIMANOV, Emil a OUELLETTE, Megan, The Participation of North Caucasian Jihadists in the Syrian Civil War and its Security Implications [on-line]. Meria Journal, Vol. 18, No. 4, Winter 2014, Dostupné z: http://www.rubincenter.org/2015/02/the-participation-of-north-caucasian -jihadists-in-the-syrian-civil-war-and-its-security-implications/

[46] STEPHENS, Michael. 2014. Islamic State: Where does jihadist group get its support? [on-line]. BBC.com, Dostupné z: http://www.bbc.com/news/world-middle-east-29004253

[47] Podobný střet sunnitských zemí Perského zálivu s šíismem a Íránem lze pozorovat na současném horkém dění v Jemenu. Více viz rozhovor J. Krause v Lidových novinách, 27. 3: 2014. Nervózní Saúdi v Jemenu krotí nepřátelský šítský půlměsíc [on-line]. Dostupné z: http://www.lidovky.cz/ nervozni-saudska-arabie-v-jemenu-kroti-nepratelsky-siitsky-pulmesic-12q-/zpravy-svet.aspx?c= A150327 123153 ln zahranici msl

[48] Rozhovor s velvyslancem na pưdě Univerzity obrany, 23. 3. 2015.

[49] Deutsche Welle, 7. 2. 2015. Jordan: United in sorrow, united against IS [on-line]. Dostupné z: http:// www.dw.de/jordan-united-in-sorrow-united-against-is/a-18242900

[50] Rozhovor autora s Markem Rochem, britským bezpečnostním pracovníkem společnosti Iraq Star pracujícím v irácké Bašre a blízkém okolí, Brno, září 2014.

[51] PORTER, Tom. 9. 3.2015. Isis: , 10,000 Europeans could be fighting for Islamic State by 2016'warns French $P M$ [on-line]. International Business Times, Dostupné z: http://www.ibtimes.co.uk/isis-10000-europeans -could-be-fighting-islamic-state-by-2016-warns-french-pm-1491082

[52] TheTrumpet.com, 9. 2. 2015. EU Steps Up Aid in Fight Against the Islamic State [on-line]. Dostupné z: https:/www.thetrumpet.com/article/12415.19.0.0/eu-steps-up-aid-in-fight-against-the-islamic-state

[53] Pro více informací o tzv. Emirátu Kavkaz viz ŠMÍD, Tomáš. Emirát Kavkaz - základní analýza islamistické vzbouřenecké struktury na severním Kavkaze, Obrana a strategie, Brno: Univerzita obrany, 2013, roč. 13, č. 2, s. 53-64. 